9 Whiskey E, Olofinjana O, Taylor D. The importance of the recognition of benign ethnic neutropenia in black patients during treatment with clozapine: case reports and database study. J Psychopharmacol 2011; 25: 842-5.

10 Pai NB, Vella SC. Reason for clozapine cessation. Acta Psychiatr Scand 2011; 124: $39-44$.

11 Taylor D, Paton C, Kapur S. Maudsley Prescribing Guidelines, 11th Edition. Wiley Blackwell, 2012.

12 Leucht S, Corves C, Arbter D, Engel RR, Li C, Davis JM. Second-generation versus first-generation antipsychotic drugs for schizophrenia: a metaanalysis. Lancet 2009; 373: 31-41.

13 Girgis RR, Phillips MR, Li X, Li K, Jiang $\mathrm{H}$, Wu C, et al. Clozapine v. chlorpromazine in treatment-naive, first-episode schizophrenia: 9-year outcomes of a randomised clinical trial. Br J Psychiatry 2011; 199: 281-8.

14 Lewis SW, Barnes TR, Davies L, Murray RM, Dunn G, Hayhurst KP, et al. Randomized controlled trial of effect of prescription for clozapine versus other second-generation antipsychotic drugs in resistant schizophrenia. Schizophr Bull 2006; 32: 715-23.

15 McEvoy JP, Liebermann JA, Stroup TS, Davis SM, Meltzer HY, Rosenheck RA et al. Effectiveness of clozapine versus olanzapine, quetiapine, and risperidone in patients with chronic schizophrenia who did not respond to prior atypical antipsychotic treatment. Am J Psychiatry 2006; 163: 600-10.

16 Couchman L, Morgan PE, Spencer EP, Flanagan RJ. Plasma clozapine, norclozapine, and the clozapine:norclozapine ratio in relation to prescribed dose and other factors: data from a therapeutic drug monitoring service. Ther Drug Monit 2010; 32: 438-47.

17 Couchman L, Bowskill SV, Handley S, Patel MX, Flanagan RJ. Plasma clozapine and norclozapine in relation to prescribed dose and other factors in patients aged $<18$ years: data from a therapeutic drug monitoring service, 1994-2010. Early Interv Psychiatry 2012; 2 Jul, doi: 10.1111/j. 1751-7893.2012.00374.x (ePub ahead of print).

18 Tiihonen J, Haukka J, Taylor M, Haddad PM, Patel MX, Korhonen P. A nationwide cohort study of oral and depot antipsychotics after first hopitalization for schizophrenia. Am J Psychiatry 2011; 168: 603-9.

19 Downs J, Zinkler M. Clozapine: national review of postcode prescribing. Psychiatr Bull 2007; 31: 384-7.

20 Patel MX, David AS. Why aren't depot antipsychotics prescribed more often and what can be done about it? Adv Psychiatr Treat 2005; 11: 203-11.

21 Best-Shaw L, Nagar J, David AS, Rose D, Patel MX. Psychiatrists' perspectives regarding antipsychotics: Dose choice and plasma level therapeutic drug monitoring. J Psychopharmacol 2012; 26 (suppl 8): A39.

22 Royal College of Psychiatrists. National Audit of Schizophrenia (NAS). Royal College of Psychiatrists, 2011. (http://www.rcpsych.ac.uk/quality/ nationalclinicalaudits/schizophrenia/nationalschizophreniaaudit.aspx).

23 Harrison PJ, Baldwin DS, Barnes TRE, Burns T, Ebmeier KP, Ferrier IN, et al. No psychiatry without psychopharmacology. Br J Psychiatry 2011; 199: 263-5. psychiatry in the movies

\section{Fraud at the polls: Charles Foster Kane defeated}

\section{Peter Byrne}

Jerry Seinfeld has no time for Olympic Silver winners: 'of all the losers, he was the best loser'. After 5 decades at the top of Sight and Sound's 10 yearly critics' poll, Orson Welles' first film has been beaten into second place. Ignore the hyperbolic (i.e. Iying) headline above: Vertigo (1958) is a convincing winner, though not in the directors' poll where Citizen Kane achieves a respectable second place to Ozu's Tokyo Story. But leave talk of second best to Shakespeare's beds. A masterpiece has not been devalued and Welles' authority is undiminished. Citizen Kane grandstands the life of Charles Foster Kane - from boy to legend to lonely old man, though not in that order. The story unfolds through conventional dramatic scenes, stylish flashbacks, contemporary newsreel (many complained of its scratches and hisses - Welles deliberately dragged original prints of this section across the floor), 'talking heads' to reporter Thompson, and montages of headlines, stills and film. Many of the performances are at once film debuts and career bests. Alongside intense human interest, mysteries abound: Rosebud? Why the angry young man? Benevolent democrat (Democrat even) or demagogic narcissist? Does wealth corrupt him or the purposelessness of his power? Set aside its technical mastery, and the film still deserves repeated viewing to establish where the Truth lies. Its insights into the uses and abuses of media invoke the Leveson Inquiry.

Welles made his name with theatre productions of Shakespeare's better known tragedies, but his protagonist - as written and acted by him - owes much to Coriolanus. He is the patriarch who will speak for the people. Outside of Shakespeare, few dramas have successfully interwoven the political with the personal. The idea to pastiche the life of newspaper magnate William Randolph Hearst was co-writer Mank's (Herman J. Mankiewicz). Mank and Welles won the film's only Oscar. On Hearst's instructions, all nine of the film's nominations were booed at the Awards ceremony. Welles shared the final title credit as director with his cinematographer Greg Toland, where most stills from this film could hang proudly on a gallery wall. The fourth creative talent (of many) is editor Robert Wise, best known for directing the Sound of Music (1965). Conflicting claims about original ideas ownership followed: Rosebud was Mank's first bicycle.

The question remains as to how a story this sad can be projected so beautifully. A voiceover tells us Kane loses his estranged wife and only son in a car accident. Feel-good cinema trades on nostalgia, but Kane explores attachment and loss, and the lies we tell ourselves before acting them out. Kane channelled his frustrations into Kane the Art Collector. The abandoned Art pieces of his Xanadu Palace are among the closing visual images, recalling Yeats:

'Players and painted stage took all my Love

And not those things that they were Emblems of.' 